Mrs. Palmer, now fellow and tutor of Newnham College, Cambridge. Another is Lady Brooke, wife of Sir J. R. Brooke, of the Electricity Commission.

This record of Sir Horace Lamb would be incomplete without referring to his sunny temperament and the vivid interest in every kind of human activity, which made him so fascinating a personality to all who had the good fortune to come into contact with him.

G. I. T.

\section{Dr. A. A. Belopolsky}

Aristarch Apollonovitch Belopolsky, the wellknown astrophysicist, member of the Russian Academy of Sciences since 1903, honorary director of the Pulkovo Astronomical Observatory in the U.S.S.R. and since 1910 an associate of the Royal Astronomical Society in London, passed away at Pulkovo on May 16, 1934, at the age of eighty years.

The main work of Belopolsky's long and laborious life was connected with spectroscopic investigations of the sun and stars. It was he who was charged in 1891 by F. A. Bredichine, then director of the Pulkovo Observatory, with planning the astrophysical equipment for use with the 30 -in. refractor, visual at first and later for photographic records. His first observations were on Nova Aurigæ, in 1892, and since he never missed any new star, he accumulated a series of valuable spectrograms and obtained in some cases pure absorption spectra characteristic of the very first stages of the outbursts. At the same time, he made spectroscopic observations of the sun and was to the last president of the Solar Committee in the U.S.S.R. He was the first to determine, in 1915, the temperature of sunspots from his spectrograms.

In 1912 the Russian Academy of Sciences placed an order with the firm of Sir Howard Grubb, then in Dublin, for a big Littrow spectrograph, of 7-metre focal distance and a dispersion in the third order of $1 \mathrm{~mm}$. $=0.76 \mathrm{~A}$. Owing to the War and succeeding adverse circumstances, the instrument did not reach Pulkovo until 1923, and Belopolsky immediately took up his part of the international research on the solar rotation.

Many beautiful records and classical discoveries testify to the knowledge and the experimental skill of Belopolsky. Thus, in 1894, he discovered the velocity variations of $\delta$ Cephei associated with the changes of light. Two years later he made the same discovery for $\eta$ Aquilæ and in 1899 for $\zeta$ Geminorum. In 1895 he confirmed Keeler's discovery of the rotation law of the rings of Saturn. From his examination of the spectra of $\gamma$ Virginis and $\gamma$ Leonis he made an important advance in the determination of the parallaxes of double stars. His favourite star, however, was Polaris, and every second year he took up the determination of its elements. A very striking achievement was his experimental proof of the Doppler effect. Already in 1894 he had set up a device consisting of a series of rapidly rotating mirrors opposed to each other, thus making it possible to get very high speeds of the reflected ray of light. In 1898 the arrangement was ready and Belopolsky was able to confirm by a purely laboratory experiment a fundamental law of modern astrophysics.

To understand this remarkable gift in the application of physics to astronomy we have to go back to Belopolsky's education. His parents were well educated but poor, and they encouraged his intellectual ambitions. The boy revelled in natural sciences, made experiments at home in physics and chemistry, and was a craftsman, achieving good results with the simplest means and making instruments practically out of nothing. He studied at the University of Moscow and graduated in 1877. F. A. Bredichine was then at the head of the Moscow Observatory; he at once appreciated the gifts of the young man and made him his assistant. In 1888 Belopolsky went to the Pulkovo Observatory, where he stayed for the remainder of his life. He published his work on sunspots and their movement in 1886 . From the beginning of the Astrophysical Journal in 1895 , he took a great interest in the periodical and was one of its associate editors.

During his career at the University of Moscow, Belopolsky had to provide for himself and knew what hardship meant. But science had captured him and he never failed her, whether in good or in hard times. He was a very kind-hearted man, with a real sense of justice and truth.

\section{Rev. T. E. EsprN}

WE regret to record the death on December 2 of the Rev. T. H. E. C. Espin, the well-known amateur astronomer. $\mathrm{H}_{\Theta}$ began observing with a 1-in. telescope while at school at Haileybury, where his interest in the heavens was aroused by the appearance of Coggia's comet in 1872, and by his form master's lectures on his favourite hobby, astronomy.

On proceeding to Oxford, where he took his degree in 1881, Espin found his first double star with a 3 -in. refractor, and evinced such enthusiasm that the Savilian professor allowed him the use of the University 13-in. At the age of twenty years ho was elected a fellow of the Royal Astronomical Society, and soon afterwards was appointed special observer to the Liverpool Astronomical Society, of which he was a founder and president. At West Kirby, Wallasey and Wolsingham, where he was curate (1881-88) to his father, Chancellor Espin, a wellknown ecclesiastical lawyer, he astonished the astronomical world by a survey of red stars, with a large reflecting telescope, of the whole of the northern heavens; he found 3,800 , a total unoqualled by any other observer. During this research more than thirty variables were discovered and observed until their range and period were determined. They included several remarkable objects, notably X. Ophiuchi, V. Cassiopeiae and $R$. Canum Venat. At the same time he almost doubled the known number of type IV stars. In $1899 \mathrm{Mr}$. Espin began a micrometrical examination of all stars shown on Argelander's charts-a total of well over 300,000-for new double stars, and before his death had found 2,575. For these researches, extending over forty years, and for the discovery of Nova Lacertae, he received the 
Jackson-Gwilt medal of the Royal Astronomical Society.

Mr. Espin invented a spectroscope, a variablepower eyepiece and Espin's star detector. On Röntgen's discovery of X-rays, he built several high tension machines, culminating in a huge 24-plate Wimshurst, with which for many years he treated invalids from all over the country. In recent years, with the collaboration of W. Milburn, his astronomical assistant, he investigated the radioactivity of local spring waters and published the results in his observatory circular for 1933 .

During the later years of his life, when he was unable to spend long hours in the observatory, Espin made and examined rock sections from his specimens collected abroad, especially of those from Vesuvius, Etna and Les Puys de Dôme. His scientific interests were thus very wide, and he brought both observation and thought to bear on many objects upon the earth as well as in the heavens. There are now few natural philosophers of his type, and his death has deprived the world of one who contributed much to its knowledge.

Mr. Ernest Binfield Haveli, whose death at the age of seventy-three years occurred on December 30, was well known as one of the foremost authorities on Indian art, architecture and technology. He first went to India as superintendent of the Madras School of Art, and in 1896 was transferred to the
Calcutta School, retiring from the Education Service in 1908. While at Calcutta he founded what has since come to be known as the Calcutta school of painting, and it was largely owing to his interest in indigenous industries that the village hand-loom industry was revived. An intense and enthusiastic appreciation of the aims of Indian art, especially of the Mogul and Rajput schools, was the basis of his conviction that the only future possible for a living school of art in India lay in an evolutionary development of the indigenous art, free from the influence of European ideals and methods. The enthusiastic welcome and support his views received from the Nationalist party in India proved an embarrassment rather than an assistance when, after his retirement, he endeavoured to promote in England a better understanding of India's artistic achievement. Mr. Havell was a voluminous writer on Indian art and technology, his best-known work being a "Handbook of Indian Art" (1920).

WE regret to announce the following deaths :

Mr. H. G. Ponting, the official photographer to the Scott Expedition of 1910-13 to the South Pole, on February 7, aged sixty-four years.

Prof. Arthur Thomson, emeritus Dr. Lee's professor of anatomy in the University of Oxford, president of the Anatomical Society of Great Britain and Ireland in 1906, on February 7, aged seventy-six years.

\section{News and Views}

\section{Ethnographical Films}

Considerable interest has been aroused by a recent announcement that the Trustees of the British Museum have accepted the donation of a cinematograph film of the life of the Worora tribe of the Kimberley district of north-west Australia. The film was presented by Mr. H. R. Balfour of Melbourne. It was taken on the Government Native Reserve of Kunmunya, and shows the present conditions of native life. Technological processes, such as the making of stone axes and spear heads, in which these people are specially skilled, the making of fire by twirling one stick on another, the spinning of human hair for thread and the like are shown as living crafts. The 'shots' also include ceremonies and dances and an emu corroboree. The film has already been shown to missionaries, learned societies and medical students in Australia; but as is explained by Sir George Hill in a letter to The Times of February 7 , owing to the fact that it was taken on a Government reserve, under the regulations of the Commonwealth Government, it cannot be shown commercially. With the permission of the Trustees of the Museum, arrangements have been made for the film to be shown at a meeting of the Royal Anthropological Institute to be held on March 19 at the London School of Hygiene and Tropical Medicine, but only fellows of the Institute and their guests can be admitted. A description of the film has been supplied by the Rev. J. R. B. Love, who is superintendent of the reserve and is well acquainted with the language of the Worora.

Although this film will, no doubt, prove of the greatest interest as an ethnographical record, it is by no means unique. The cinematograph camera has long been used as an adjunct to ethnographical exploration. One of the earliest records of this kind was the series taken by Prof. C. G. Seligman when a member of the Cooke Daniels-Seligman expedition to New Guinea thirty years ago, which was shown at the Leicester meeting of the British Association in 1907 ; and the late Sir Baldwin Spencer showed a detailed record of the life and corroborees of the natives of northern Australia at a meeting of the Royal Anthropological Institute in 1914. The diffidence felt by the Trustees of the British Museum in accepting the gift, notwithstanding the fact that it was a 'non-flam' film, has directed attention to the fact that the British Museum possesses one other film only, and that there is no official collection in Britain of these extremely valuable records of the life of primitive peoples, now rapidly passing away.

THE possibility of forming such a collection or repository was one of a number of points connected with the making, selection and preservation of cinematograph films of anthropological and ethnographical 